\title{
GRAIN GROWTH AND YIELD OF WHEAT UNDER DIFFERENT IRRIGATION REGIMES
}

\author{
S. A. Haider*, M. Z. Alam and N. K. Paul \\ Crop Physiology Laboratory, Department of Botany \\ University of Rajshahi, Rajshahi 6205, Bangladesh
}

\begin{abstract}
A field experiment was carried out to study the influence of different irrigation regimes on the panicle and grain growth, relative growth rate of grain, grain abortion, yield and some yield components of four wheat varieties in two growing seasons. Irrigation regimes had significant effects on the aforesaid parameters and the varieties were found to be more efficient under well irrigated conditions. A drastic reduction in panicle and grain growth and yield and increase in grain abortion was noticed when the varieties were grown under rainfed condition. C 306 was found to be the most efficient to have higher values of panicle and grain growth, relative grain growth rate and yield under all the irrigation regimes in both the growing seasons.
\end{abstract}

Key words: Wheat, irrigation, relative growth rate, grain abortion

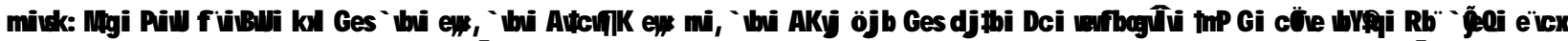

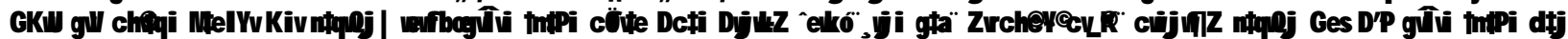

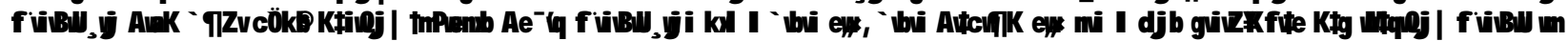

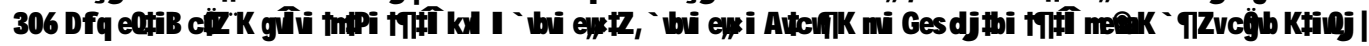

\section{Introduction}

Wheat is largely grown in Bangladesh during the period of November-March when stored soil moisture soil moisture is depleted rapidly, especially in the later part of crop growth. As a consequence, the yield of wheat is depressed significantly. In low soil moisture condition, the growth rate of grains determines the grain yield. Yield can be related to the number of flowers produced (Dominguez and Hume 1978) or inversely related to the percentage of total flower and grain abortion (Hardman and Brun 1971). Various environmental factors including soil moisture influence grain abortion and growth of wheat. The present experiment was conducted to study the effects of soil moisture on panicle and grain growth, grain abortion and yield of four bread wheat varieties over two growing seasons.

\section{Materials and Methods}

The experiment was carried out in the Botanical Research field of Rajshahi University, Bangladesh with Triticum aestivum L. varieties, e.g., Akbar, Opata, Protiva and C 306. The soil of the experimental field was silty loam having a $\mathrm{pH}$ of 7.5 , low in organic carbon $(0.44 \%)$, total $\mathrm{N}$ (0.43\%), available P (15 ppm) and K (82 ppm). The field capacity of the soil was $34 \%$ at the beginning and end of the experiment. A basal dose of urea (80 kg ha-1), TSP (60 $\mathrm{kg} \mathrm{ha}^{-1}$ ) and MP (30 kg ha-1) were added to the soil before seeding. The experimental design was a split-split plot with three irrigation treatments $\left(\mathrm{I}_{0}=\right.$ rainfed, $\mathrm{I}_{1}=10 \mathrm{~mm}$ irrigation and $\mathrm{I}_{2}=20 \mathrm{~mm}$ irrigation) and three replications *Corresponding author: haider_rubd@yahoo.com in each treatment for every individual variety. The total experimental field was divided into three main plots (treatments). Each plot was again subdivided into three replication plots of $5 \times 3.4 \mathrm{~m}^{2}$ each containing all the four varieties assorted randomly. Seeds were sown on $15^{\text {th }}$ November, first irrigation treatment was applied at 18 days after sowing and the later were at 15 days interval manually over the $I_{1}$ and the $I_{2}$ plots. The total amount of water received as irrigation was $0 \mathrm{~mm}, 50 \mathrm{~mm}$ and 100 $\mathrm{mm}$ for the $\mathrm{I}_{0}, \mathrm{I}_{1}$ and $\mathrm{I}_{2}$ plots respectively.

At 50\% anthesis, twenty five plants of each variety from each replication of each treatment were tagged. Two panicles of a variety from 7 days after anthesis (DAA) at an interval of 7 days up to the maturity at final harvest were collected. Weights of panicle and grain were taken after oven-drying at $85^{\circ} \mathrm{C}$ for 48 hours when a constant weight was obtained. The selection of appropriate polynomial regression model was made by 'lack of fit' method and the functional techniques of growth analysis were followed to obtain the fitted values according to Nicholls and Calder (1973). The percentages of grain abortion for all the replications were also calculated. Six plants/ replication/ treatment/ variety were harvested finally at maturity to determine the yield and yield component characters, e.g., number of spikelet/panicle, grain yield/panicle, 100-seed weight and commercial yield. The total experiment was carried out during the growing seasons of 1998-1999 for the first year and 1999-2000 for the second year. 
Table 1. Yield and yield components at maturity of four wheat varieties as influenced by different irrigation regimes in two seasons.

\begin{tabular}{lcccccc} 
& \multicolumn{3}{c}{ First year } & \multicolumn{3}{c}{ Second year } \\
\hline & \multicolumn{1}{c}{$\mathbf{I}_{\mathbf{0}}$} & $\mathbf{I}_{\mathbf{1}}$ & $\mathbf{I}_{\mathbf{2}}$ & $\mathbf{I}_{\mathbf{0}}$ & $\mathbf{I}_{\mathbf{1}}$ & $\mathbf{I}_{\mathbf{2}}$ \\
\hline Akbar & $16.22 \mathrm{ab} 18.50 \mathrm{a}$ & $18.06 \mathrm{a}$ & $17.82 \mathrm{c}$ & $18.92 \mathrm{bc} 19.15 \mathrm{~b}$ \\
Opata & $17.50 \mathrm{a}$ & $18.24 \mathrm{a}$ & $18.81 \mathrm{a}$ & $19.65 \mathrm{a}$ & $20.78 \mathrm{a}$ & $20.45 \mathrm{a}$ \\
Protiva & $15.88 \mathrm{~b}$ & $16.94 \mathrm{~b}$ & $17.59 \mathrm{a}$ & $17.73 \mathrm{c}$ & $18.15 \mathrm{c}$ & $19.50 \mathrm{~b}$ \\
C 306 & $17.30 \mathrm{a}$ & $18.96 \mathrm{a}$ & $18.48 \mathrm{a}$ & $18.65 \mathrm{~b}$ & $19.33 \mathrm{~b}$ & $19.82 \mathrm{ab}$ \\
\hline Akbar & $3.90 \mathrm{~b}$ & $5.94 \mathrm{~b}$ & $6.48 \mathrm{a}$ & $5.39 \mathrm{a}$ & $5.92 \mathrm{~b}$ & $6.43 \mathrm{a}$ \\
Opata & $3.71 \mathrm{~b}$ & $5.47 \mathrm{~b}$ & $6.28 \mathrm{a}$ & $4.61 \mathrm{~b}$ & $7.40 \mathrm{a}$ & $5.37 \mathrm{~b}$ \\
Protiva & $3.96 \mathrm{~b}$ & $5.41 \mathrm{~b}$ & $6.26 \mathrm{a}$ & $4.56 \mathrm{~b}$ & $4.15 \mathrm{c}$ & $4.71 \mathrm{c}$ \\
C 306 & $5.47 \mathrm{a}$ & $6.89 \mathrm{a}$ & $7.13 \mathrm{a}$ & $4.50 \mathrm{~b}$ & $5.72 \mathrm{~b}$ & $6.90 \mathrm{a}$ \\
\hline Akbar & $4.12 \mathrm{a}$ & $4.17 \mathrm{a}$ & $4.20 \mathrm{a}$ & $4.39 \mathrm{a}$ & $4.52 \mathrm{a}$ & $4.31 \mathrm{a}$ \\
Opata & $2.80 \mathrm{c}$ & $3.05 \mathrm{c}$ & $3.14 \mathrm{~b}$ & $3.41 \mathrm{~b}$ & $3.55 \mathrm{~b}$ & $3.38 \mathrm{~b}$ \\
Protiva & $3.66 \mathrm{~b}$ & $3.83 \mathrm{ab}$ & $4.02 \mathrm{a}$ & $4.31 \mathrm{a}$ & $4.37 \mathrm{a}$ & $4.31 \mathrm{a}$ \\
C 306 & $3.74 \mathrm{ab}$ & $3.54 \mathrm{~b}$ & $3.91 \mathrm{a}$ & $4.28 \mathrm{a}$ & $4.36 \mathrm{a}$ & $4.09 \mathrm{ab}$ \\
\hline Commercial yield (kg ha-1) & & & \\
\hline Akbar & $3901 \mathrm{~b}$ & $5940 \mathrm{~b}$ & $6476 \mathrm{a}$ & $5386 \mathrm{a}$ & $5916 \mathrm{a}$ & $6433 \mathrm{~b}$ \\
Opata & $3708 \mathrm{~b}$ & $5465 \mathrm{~b}$ & $6278 \mathrm{a}$ & $4605 \mathrm{~b}$ & $5656 \mathrm{~b}$ & $5373 \mathrm{c}$ \\
Protiva & $3960 \mathrm{~b}$ & $5415 \mathrm{~b}$ & $6263 \mathrm{a}$ & $4560 \mathrm{~b}$ & $4146 \mathrm{c}$ & $4705 \mathrm{~d}$ \\
C 306 & $5473 \mathrm{a}$ & $6886 \mathrm{a}$ & $7133 \mathrm{a}$ & $4498 \mathrm{~b}$ & $5720 \mathrm{~b}$ & $6895 \mathrm{a}$ \\
\hline
\end{tabular}

In a column, means followed by a common letter are not significantly different at $5 \%$ level by Duncan's Multiple Range Test.

\section{Results and Discussion}

Influence of different irrigation regimes on panicle growth is shown in Figures $1 \mathrm{a}$ and $1 \mathrm{~b}$ for the first and the second year, respectively. Starting from a lower value, panicle weight increased with time. Irrigation regimes had significant effect on panicle growth from 21 DAA onwards in almost all occasions and the rainfed treatment $\left(\mathrm{I}_{0}\right)$ resulted in the lowest panicle weight in all four varieties in both seasons. The $I_{2}$ plants had the highest value of panicle weight in all occasions except Akbar and Opata in the first year and Protiva in the second year. Significantly higher panicle weight was found in C 306 and lower in Akbar in both the growing seasons. Panicle weight was reduced under rainfed condition and this result was in agreement with that of Nicolas et al. (1985) and Rahman and Paul (1996).

Increase in grain weight per panicle of four wheat varieties at successive stages of growth is presented in Figures $2 \mathrm{a}$ and $2 \mathrm{~b}$ for the first and the second year, respectively. Significant effect of irrigation on grain growth was noticed and the rainfed condition resulted in reduced grain growth in all the varieties. According to Evans and Wardlaw (1976), the number of grains that develop in a panicle of wheat is dependent on the number of florets and the effective fertilization of them after anthesis. It has been reported that grain weight per panicle is dependent on the number of grains and its size and shape (Amin et al. 1995). Water stress during grain filling has a detrimental effect on panicle weight and subsequently grain yield through a shortening of the grain filling duration (Bagga and Rawson 1977). Lalonde et al. (1997) reported that water stress during meiosis in microspore mother cells of wheat induced male sterility which resulted in reduced grain yield. The highest grain weight per panicle was found in the $\mathrm{I}_{2}$ plants in all the varieties for both the growing seasons and it was followed by the $\mathrm{I}_{1}$ and $\mathrm{I}_{0}$ plants. The differences in grain weight per panicle between the varieties within the treatment and between treatments within variety were significant in all occasions in both the growing seasons. C 306 had the highest grain weight per panicle in each treatment for both the growing seasons.

Irrigation effects on relative growth rate (RGR) of grain calculated from the quadratic fitted values are shown in Figs 3a and 3b. Higher RGR of all the varieties was noticed at the early stages and then declined with increasing plant age for all the irrigation regimes. Continuous reduction is a common response among the wheat varieties due to abiotic stresses (Ford 1976 and Kolderup 1979). The reason for higher prematurity of grains in the $\mathrm{I}_{0}$ plants might be due to the water shortage during the three or four weeks after flowering and water stress along with high temperature at the grain developing stages resulted in decreasing RGR of grain and this result is similar to Nass et al. (1975) and Sairam et al. (1992).

Higher grain abortion was noticed at the early stages of the reproductive phase and decreased at the later stages of grain growth with moderate fluctuations (Figs 4a and 4b). Irrigation regimes had significant effect on grain abortion and the $\mathrm{I}_{0}$ plants had the highest rate, followed by $I_{1}$ and $I_{2}$ plants for all the varieties in both years. Grain abortion remained higher up to 28 DAA. The highest rate of grain abortion was found in Akbar at 21 DAA over all irrigation regimes and C 306 had the least effect of irrigation on grain abortion. Higher grain abortion percentage due to water stress was also reported by Rahman and Paul (1996) in wheat. 

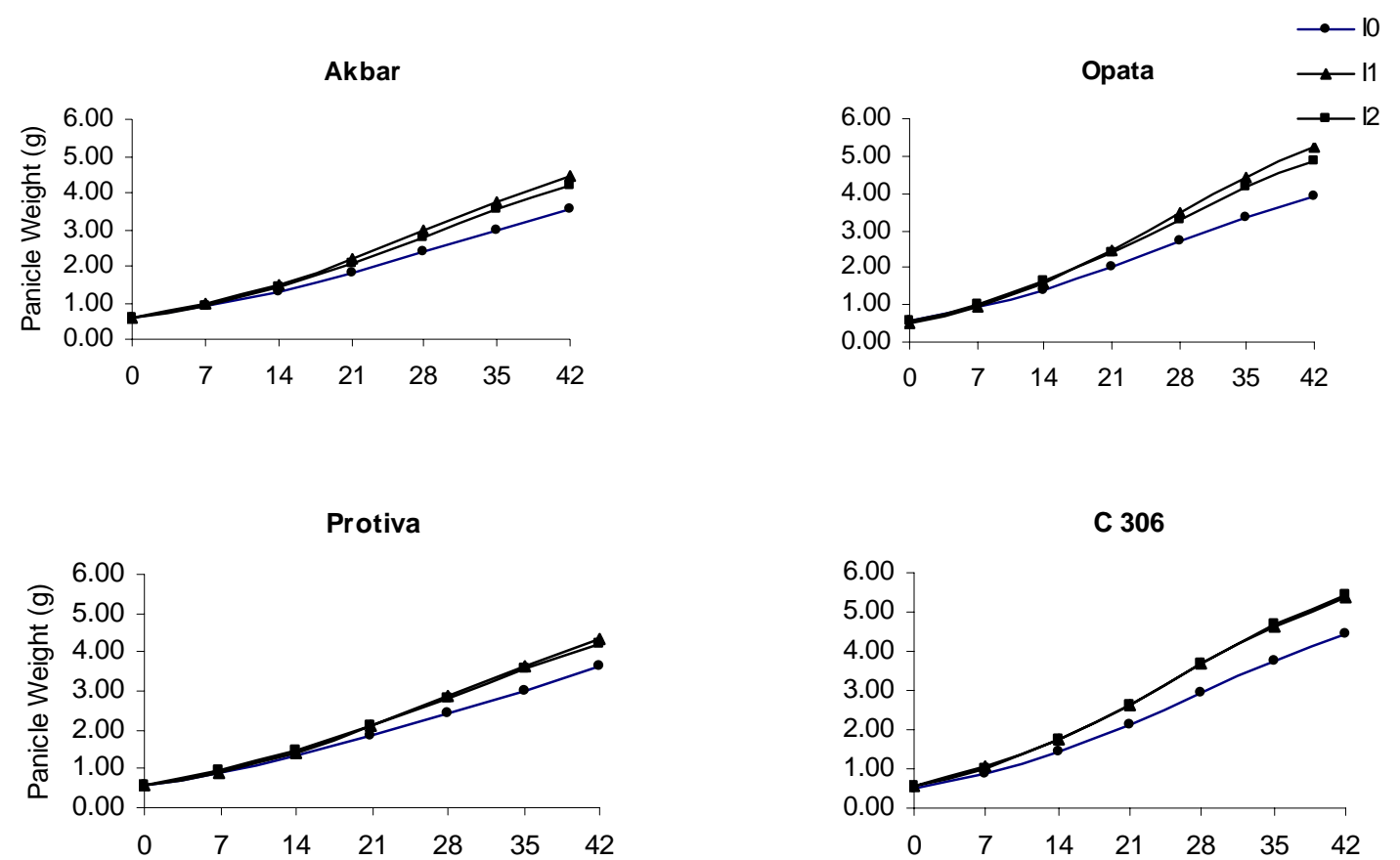

Days after anthesis

Fig. 1a. Panicle growth of four wheat varieties as affected by different irrigation regimes (First year)
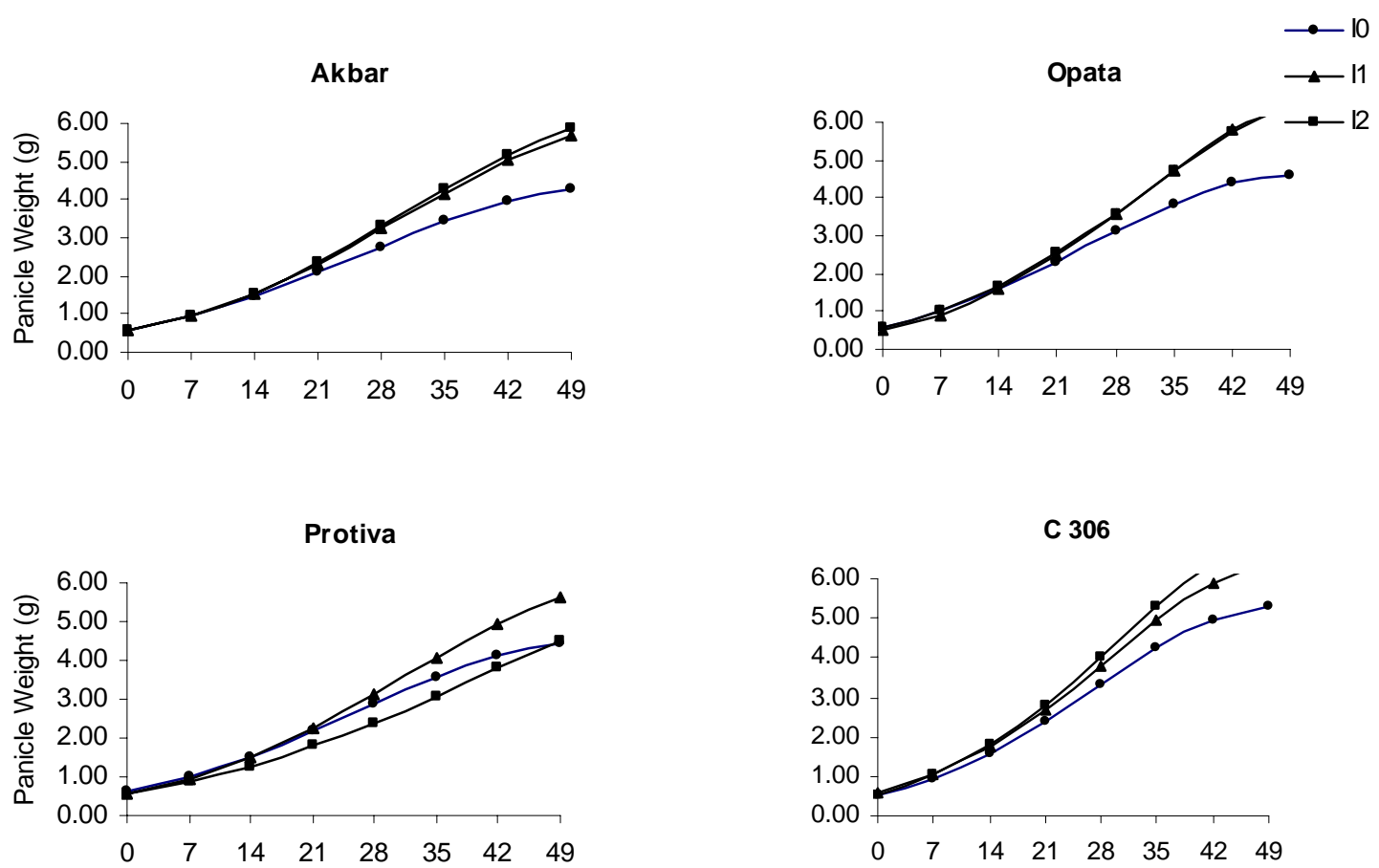

Days after anthesis

Fig. 1b. Panicle growth of four wheat varieties as affected by different irrigation regimes (Second year). 

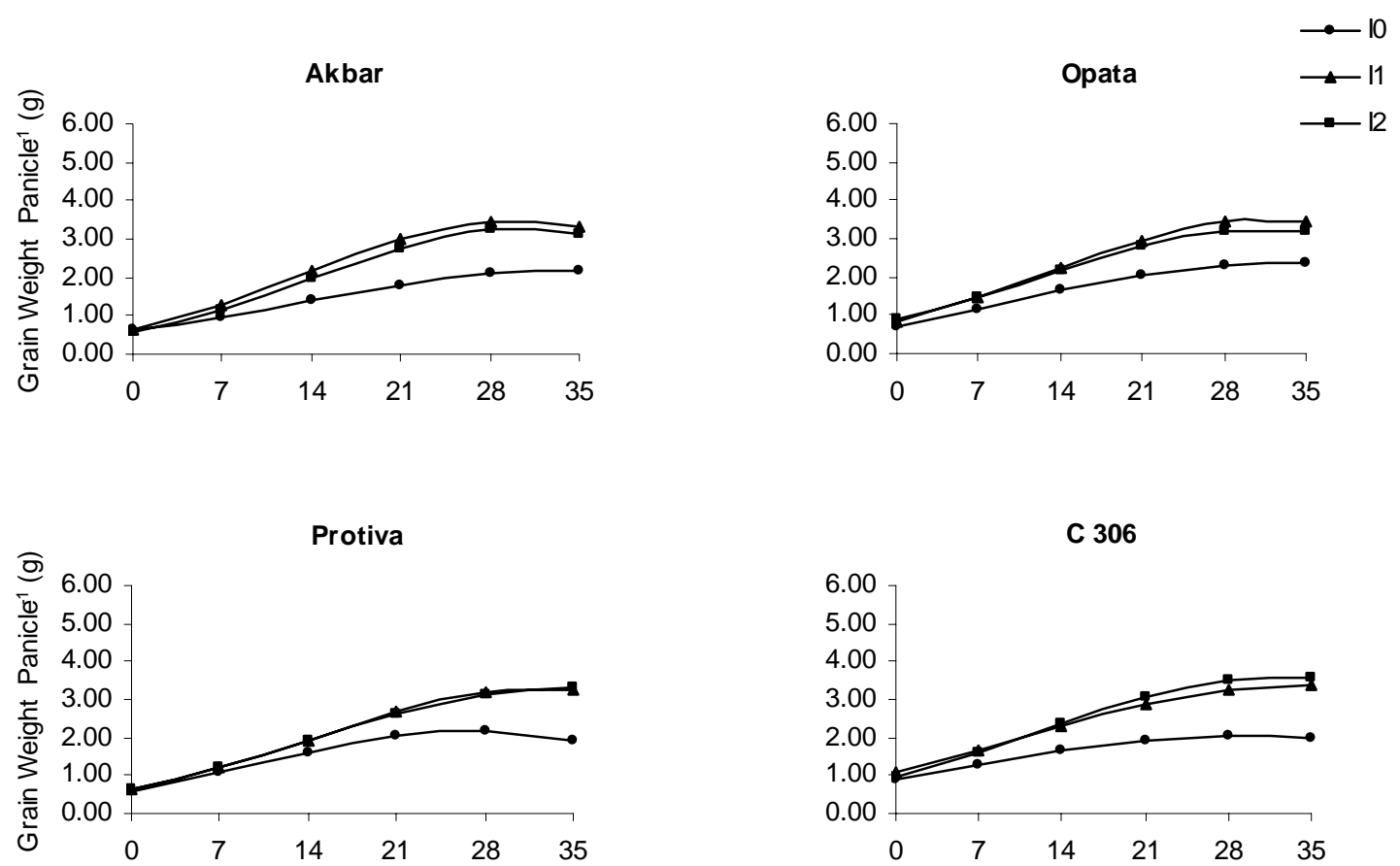

Days after anthesis

Fig. 2a. Grain growth of four wheat varieties as affected by different irrigation regimes (First year).
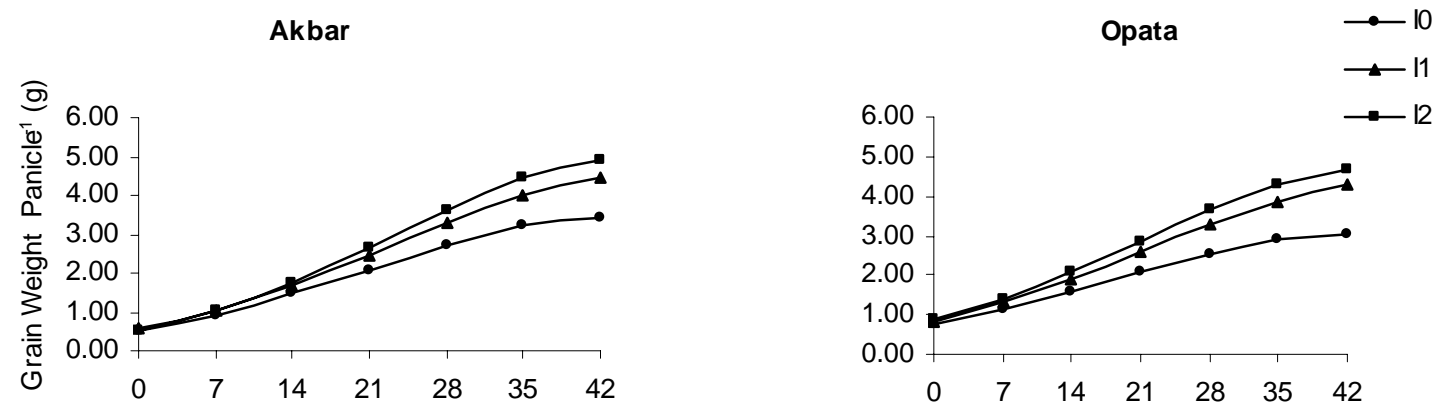

Protiva

C 306
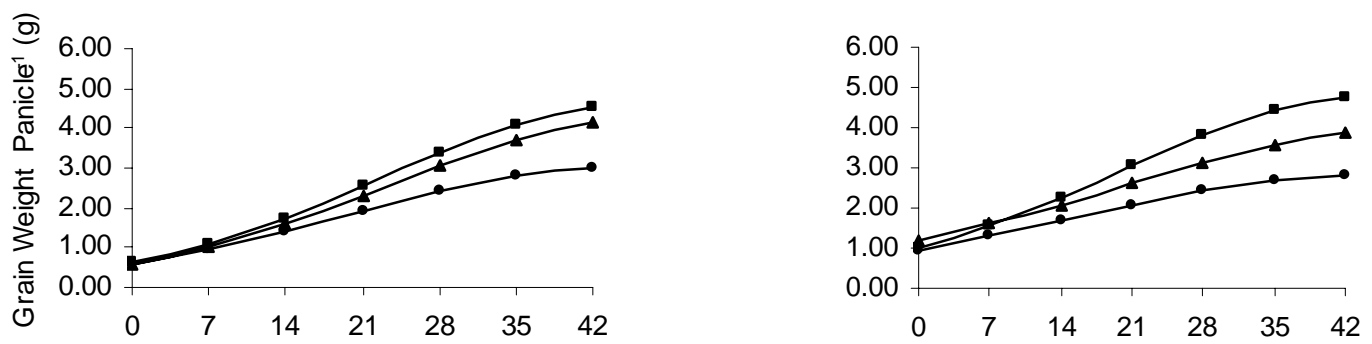

Days after anthesis

Fig. 2b. Grain growth of four wheat varieties as affected by different irrigation regimes (Second year). 

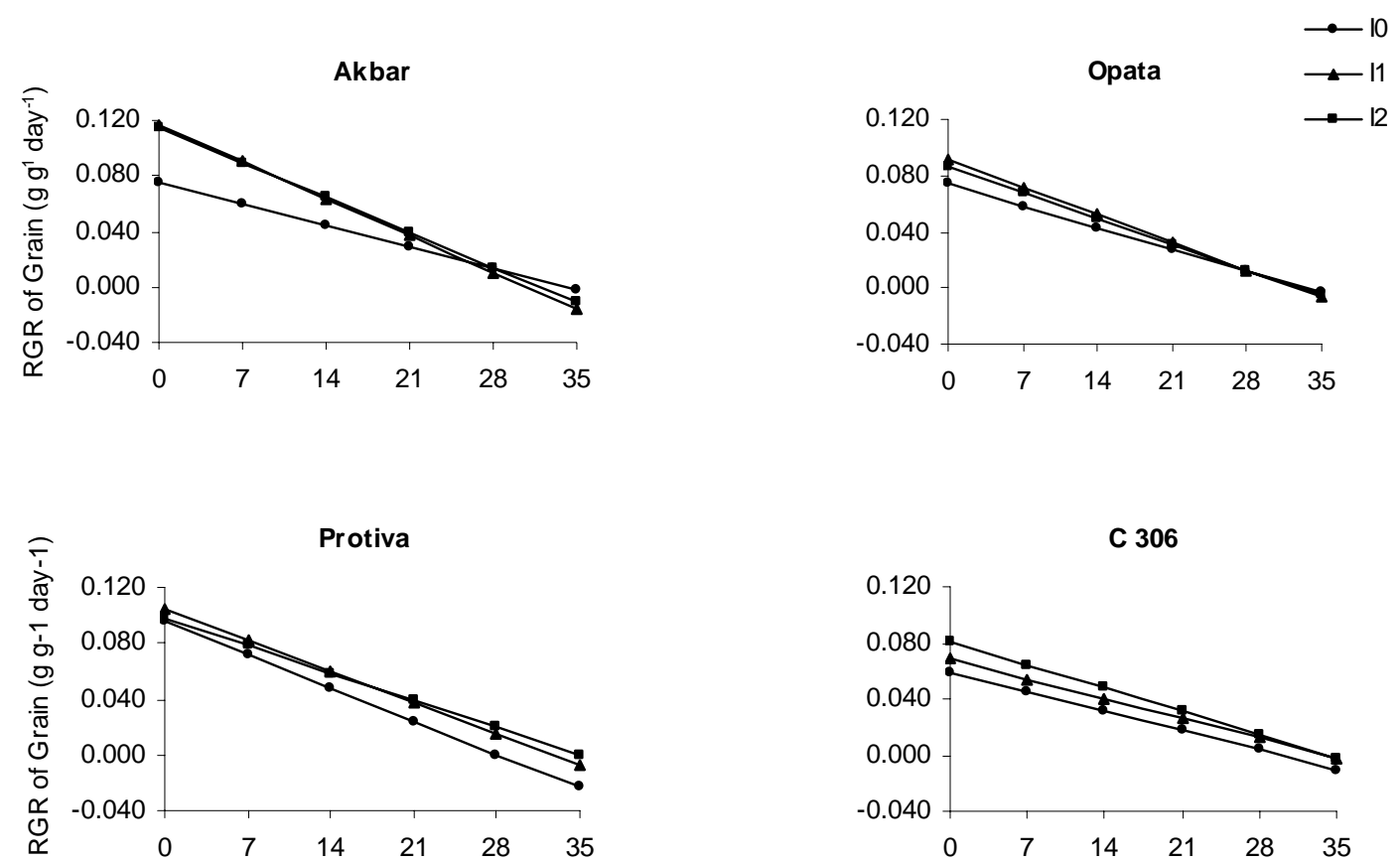

Days after anthesis

Fig. 3a. Relative growth rate of grain of four wheat varieties as affected by different irrigation regimes (First year).
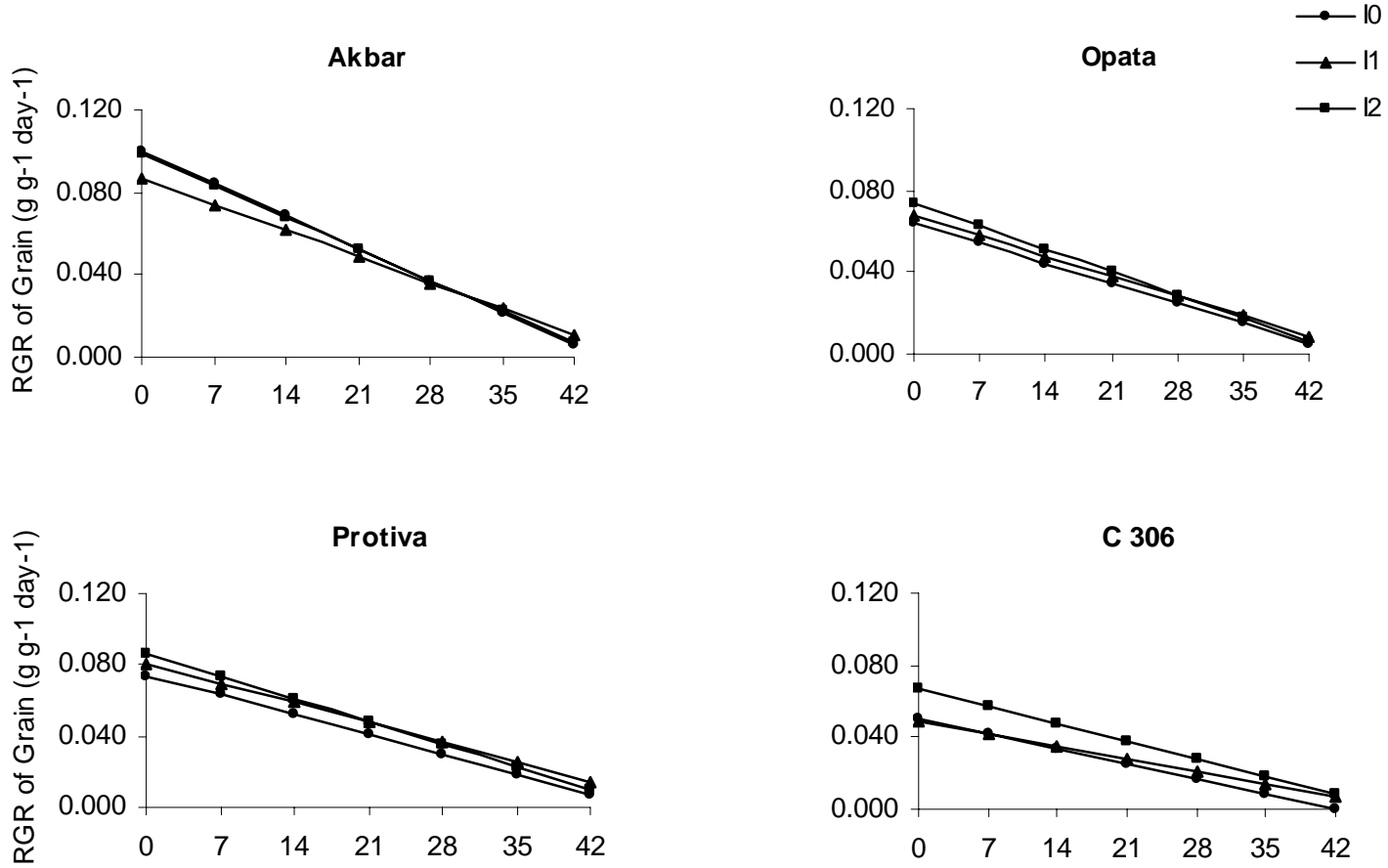

Days after anthesis

Fig. 3b. Relative growth rate of grain of four wheat varieties as affected by different irrigation regimes (Second year). 

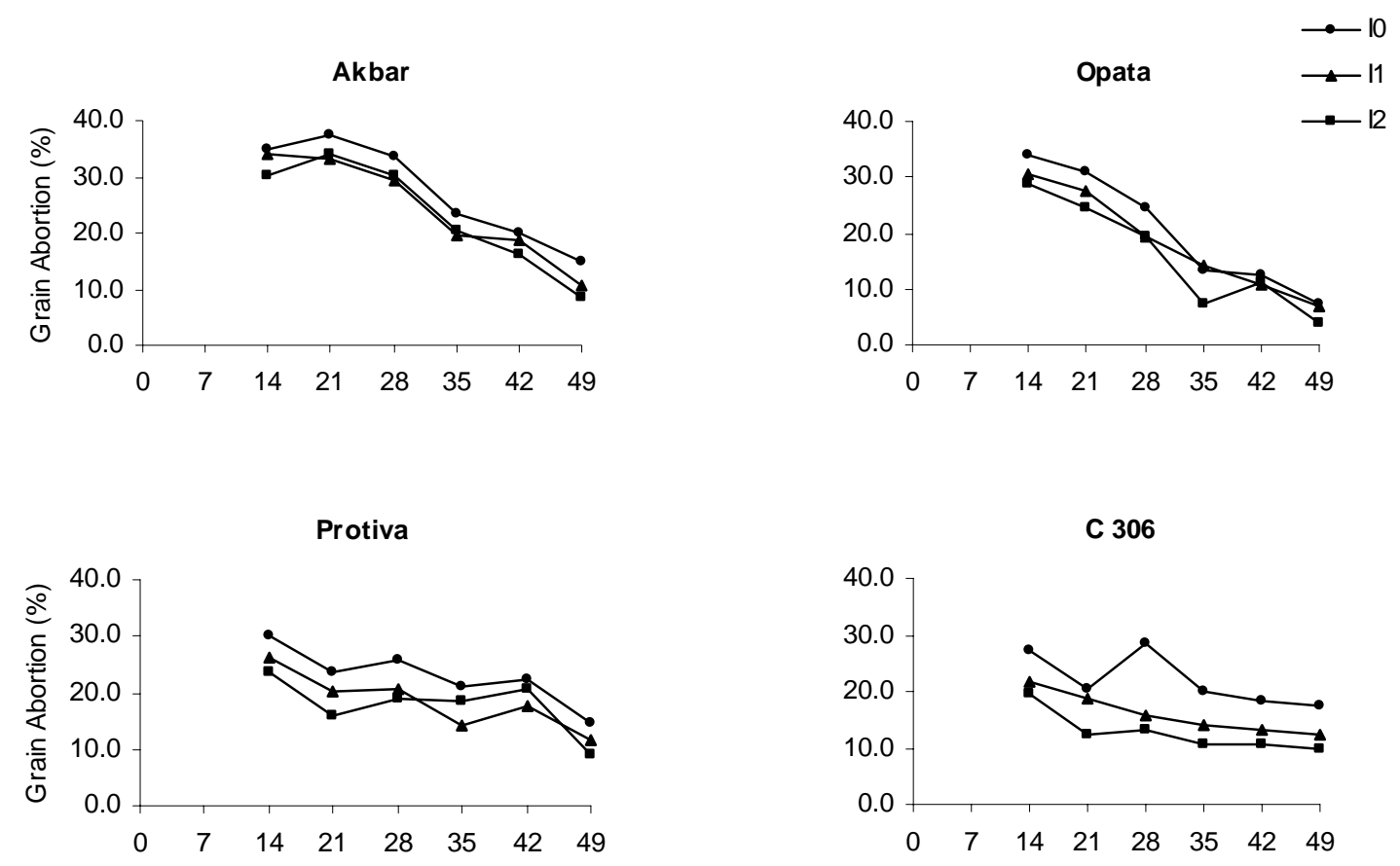

\section{Days after anthesis}

Fig. 4a. Grain abortion of four wheat varieties as affected by different irrigation regimes (First year).
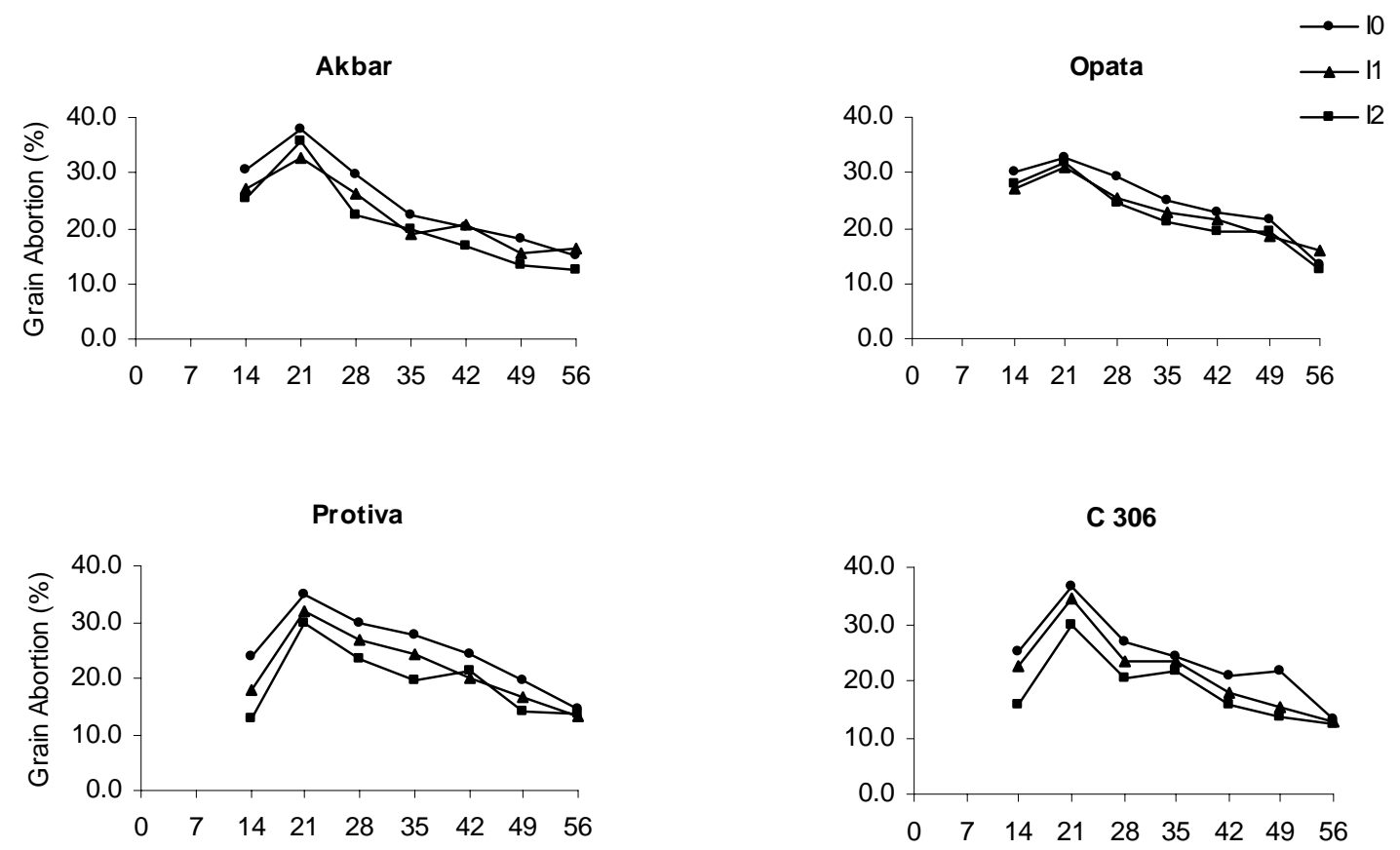

Days after anthesis

Fig. 4b. Grain abortion of four wheat varieties as affected by different irrigation regimes (Second year). 
Grain yield and some yield components were significantly affected by water stress in the present study (Table 1). Number of spikelets per panicle, grain yield per plant, 100-seed weight and commercial yield of all the four varieties were noticed to be higher in the wellirrigated $\mathrm{I}_{2}$ plants. Reduction in yield and yield components due to water stress was also reported in wheat by many workers (Rahman and Paul 1998; Destro et al. 2001; Guttieri et al. 2001). Different varieties responded differently under each irrigation regimes and $\mathrm{C}$ 306 was found to have higher values of different yield components than the other three varieties. Significant differences in yield were noticed between varieties within treatment and the lowest yield was found in Protiva under each irrigation regimes in most cases.

\section{Conclusion}

Water stress may affect every stage of plant growth and physiology, especially the reproductive phase. The effect of water stress is mainly related to the hastening of reproductive development and shortening of the developmental phases during which the various components of yield are determined. Rainfed condition decreased panicle and grain growth and relative growth rate of grain along with yield and some yield components and increased grain abortion. C 306 was found to be an efficient wheat variety which may be grown in the areas where irrigation facilities are limited to obtain satisfactory growth and yield.

\section{References}

Amin MR, Bodruzzaman M, Shaheed A, Razzaque MA. 1995. Effect of size of wheat seed on yield. Bangladesh J Agril Sci 22, 347-349.

Bagga AK, Rawson HM. 1977. Contrasting response of morphologically similar wheat cultivars to temperatures appropriate to warm temperature climates with hot summers. A study in controlled environment. Aust J Plant Physiol 4, 877-887.

Destro D, Miglioranza E, Arias CAA, Vendrame JM, de Almeida JCV. 2001. Main stem and tiller contribution to wheat cultivars yield under different irrigation regimes. Brazilian Archives of Biology and Technology 44(4), 325-330.
Dominguez C, Hume DJ. 1978. Flowering, abortion and yield of early maturing soybean at three densities. Agron J 70, 801-805.

Evans LT, Wardlaw IF. 1976. Aspects of comparative physiology of grain yield in cereals. Adv Agron 28, 301-359.

Ford MA. 1976. Effects of variation in ear temperature on growth and yield in spring wheat. Ann appl Biol 82, 317-333.

Guttieri MJ, Stark JC, O’Brien K, Souza E. 2001. Relative sensitivity of spring wheat grain and quality parameters to moisture deficit. Crop Sci 41(2), 327-335.

Hardman LL, Brun WA. 1971. Effect of carbon dioxide enrichment at different developmental stages on growth and yield components of soybeans. Crop Sci 11, 886-888.

Kolderup F. 1979. Application of different temperatures in three growth phases of wheat. I. Effects on grain and straw yields. Acta Agric Scand 29, 6-10.

Lalonde S, Beebe DU, Saini HS. 1997. Early signs of disruption of wheat anther development associated with the induction of male sterility by meiotic-stage water deficit. Sexual Plant Reproduction 10(1), 40-48.

Nass HG, Johnston HW, Macleod JA, Sterling DE. 1975. Effect of seeding date, seed treatment and foliar sprays on yield and other agronomic characters of wheat, oats and barley. Can J Plant Sci 55, 41-47.

Nicholls AO, Calder DM. 1973. Comments on the use of regression analysis for the study of plant growth. New Phytol 72, 571-581.

Nicolas ME, Gleadow RM, Dalling MJ. 1985. Effect of postanthesis drought on cell division and starch accumulation in developing wheat grains. Ann Bot 55(3), 433-444.

Rahman MS, Paul NK. 1998. Effect of soil moisture regimes on physiological characters and yield of wheat cultivars. J bio-sci 6, 5-10.

Rahman MS, Paul NK. 1996. Effect of soil drought on grain growth and grain abortion of wheat. J bio-sci 4, 151-154.

Sairam RK, Deshmukh PS, Shukla DS. 1992. Effect of chlormequat chloride on grain yield of wheat (Triticum aestivum) under moisture stress in pot culture. Indian $\mathrm{J}$ agric Sci 62(4), 282-285. 